\title{
Flexibility of K3 and ProTaper Universal Instruments
}

\author{
Renata GRAZZIOTIN-SOARES ${ }^{1}$ \\ Flares BARATO FILHO ${ }^{2,3}$ \\ José Roberto VANNI ${ }^{4}$ \\ Susimara ALMEIDA ${ }^{2,3}$ \\ Elias Pandonor Motcy de OLIVEIRA ${ }^{1}$ \\ Fernando Branco BARLETTA $^{1}$ \\ Orlando LIMONGI ${ }^{1}$
}

\begin{abstract}
${ }^{1}$ Department of Restorative Dentistry, Dental School, ULBRA - Lutheran University of Brazil, Canoas, RS, Brazil
${ }^{2}$ Department of Dentistry, Dental School, Positivo University, Curitiba, PR, Brazil

${ }^{3}$ Department of Dentistry, Dental School, Joinville Region University, Joinville, SC, Brazil

${ }^{4}$ Department of Dentistry, Dental School, Meridional University, Passo Fundo, RS, Brazil
\end{abstract}

\begin{abstract}
This study used a mechanical test to evaluate the flexibility of instruments from the K3 (conicity 0.04) and the ProTaper Universal systems when they were new and after 5 uses in simulated canals. Five sets of instruments of each system were tested: K3 (15, 20, 25, 30, 35, 40 and 45) and ProTaper Universal (S1, S2, F1, F2, F3, F4 and F5). Each set of instruments was used to prepare a simulated canal and the same set of instruments was used 5 times (50 canals). The number of each subgroup represented the number of uses: 0 (control), 1, 3 and 5 uses. Before and after each use, the instruments were submitted to a mechanical flexibility test performed in a Versat 502 universal testing machine. Interactions between the instrument and the number of uses were analyzed by ANOVA and Tukey's test at a 5\% level of significance. Instruments from both systems presented lower flexibility after the third use compared to the flexibility obtained after uses 0 and $1(\mathrm{p}<0.05)$, and maintained the same flexibility after the fifth use. The flexibility of instruments from the K3 system decreased with the increase of diameter, irrespective of the number of uses. Among the instruments from the ProTaper Universal system, the shaping files presented greater flexibility than the finishing files. F2 and F3 were the least flexible instruments, and F4 and F5 presented flexibility values similar to those of F1.
\end{abstract}

Key Words: Endodontics, nickel, root canal preparation, titanium, flexibility.

\section{INTRODUCTION}

The mechanical properties of endodontic instruments, like flexibility, are affected by several factors, such as caliber, conicity, design, chemical composition of the metallic alloy and thermomechanical processes applied during manufacturing (1-7). In addition, the form of the cross section affects the stress distribution patterns on the instrument and the behavior of the instrument when submitted to flexural and torsional forces (4).

Instrument flexibility changes are reported in studies using flexural and torsional tests $(2,4)$, clinical fatigue tests $(8,9)$ and three-dimensional models using the finite elements technique $(7,10,11)$. More imperfections (cutting point deterioration, spiral distortion, surface wear, etc.) in rotary nickel-titanium (NiTi) instruments occur as they are used a greater number of times (12).

Considering that there is no consensus regarding the number of times a NiTi instrument can be used safely, endodontists have been left without a reliable recommendation to address this issue. Studies have suggested different number of uses for a NiTi instrument (8,13-15) due to the different types of instruments and several research protocols used.

This way, although a significant rate of deformations and fractures after use has been reported (5), it has already been demonstrated that K 3 instruments

Correspondence: Prof. Dr. Flares Baratto Filho, Rua Professor Pedro Viriato Parigot, 5300, 81280-330 Curitiba, PR, Brasil. Tel: +55-41-3317-3406. Fax: +55-41-3317-3082. e-mail: fbaratto@uol.com.br 
remained intact, without distortion, and with little surface wear after the fifth use (12).

During root canal preparation, endodontic instruments are subjected to different forces, including flexion, torsion, traction and apical pressure (10). Thus, they should have properties capable of preventing mechanical failure and also minimizing the possibility of undesirable alterations in canal anatomy. Loss of flexibility may result in ledges, transportations and perforations. Bearing this in mind, the aim of the present study was to analyze the flexibility of instruments from the K3 (Sybron Endo, Glendora, CA, USA) and the ProTaper Universal (Dentsply Maillefer, Ballaigues, Vaud, Switzerland) systems. The null hypothesis of this research is that the flexibility of the instruments does not change after use.

\section{MATERIAL AND METHODS}

Five sets of NiTi instruments of each system were used in the study, as follows: K3 (Sybron Endo): taper 0.04: 15, 20, 25, 30, 35, 40 and 45; ProTaper Universal (Dentsply Maillefer): S1, S2, F1, F2, F3, F4 and F5.

Fifty simulated canals were fabricated in epoxy resin (Odontofix Indústria e Comércio de Material Odontológico, Ribeirão Preto, SP, Brazil) with the following characteristics were used: curvature of 35 degrees, radius of $5 \mathrm{~mm}$ and length of $17 \mathrm{~mm}$, of which the upper $8 \mathrm{~mm}$ corresponded to the straight portion and the lower $9 \mathrm{~mm}$ corresponded to the curved portion of the canal.

Each set of instruments (K3 or ProTaper) was employed to prepare 5 simulated canals. Immediately after removal from their packages, the instruments were cleansed by brushing and ultrasonication in an ultrasonic tank (Biodont, Brodowsky, SP, Brazil) containing enzymatic detergent (Rioquímica, São Paulo, SP, Brazil), for $20 \mathrm{~min}$. Once dry, the instruments were placed in metal boxes identified with the name of the system and the number of uses, and then inserted in envelopes for sterilization. They were sterilized in an autoclave (Cristófoli, Campo Mourão, PR, Brazil) by exposure to wet heat, $1 \mathrm{~atm}$ pressure, $127^{\circ} \mathrm{C}$, for $20 \mathrm{~min}$. The same cleansing and sterilization procedures were carried out after each use.

The instruments were divided into two groups according to the system used to prepare the canals, either K3 or ProTaper Universal System. The number of the subgroups represented the number of uses: 0 (control),
1,3 and 5 uses.

The instruments were submitted to a mechanical flexibility test before using and after each use. After conducting a pilot project and training, a flexibility test was conducted by a single operator. The measurements were performed in a Versat 502 machine (Panambra, Cambuci, SP, Brazil). The electronic panel of the machine displayed the force $(\mathrm{N})$ required to cause a displacement $(\mathrm{mm})$ of one of the machine's arms. Therefore, in order to assess the force required to curve the instrument up to 40 degrees, a progressive displacement of the instrument shaft had to be produced until reaching a 40-degree curvature.

The handle of the instrument was fixed in a set of metallic pieces especially designed and fabricated for this purpose. A copper wire $0.5 \mathrm{~mm}$ in diameter was fastened at $1 \mathrm{~mm}$ from the tip of the instrument shaft with a small amount of cyanoacrylate-based adhesive (Loctite, São Paulo, SP, Brazil). The instrument was maintained horizontally and the copper wire pulled the instrument shaft perpendicularly to its long axis. As the arm of the machine (containing the set of metallic pieces and the endodontic instrument) moved downward, the copper wire remained still (fastened to the fixed part of the machine), thus pulling the instrument shaft. The instrument was pulled until reaching a 1-mm displacement, at which time the machine's movement was interrupted and the instrument was photographed by a digital camera set on a tripod. Afterwards, the image was transferred to a computer and printed out. A protractor was then used on the printed copy to measure the angle drawn by the instrument shaft. Subsequently, the movement of the machine was interrupted at every $1-\mathrm{mm}$ displacement, and the instrument was photographed for posterior measurement of the angle formed on the printed image, until a 40-degree angle was observed. The displacement and corresponding force values required for each instrument to reach a 40-degree curvature were tabulated.

The simulated canals were mounted in a vise with the curvature facing the right side of the operator - an endodontist previously trained for both techniques under study (K3 and ProTaper Universal). The instruments were driven by an electric motor (VK Driller Electric Equipments Ltda., São Paulo, SP, Brazil) at $300 \mathrm{rpm}$ and $2 \mathrm{~N} / \mathrm{cm}$ torque. Before and during instrumentation, the canals were irrigated with $1 \mathrm{~mL}$ of anionic detergent solution (Biodinâmica, Ibiporã, PR, Brazil) at each instrument change. The solution was injected into the 
canal with a luer-lock syringe (Ibrás CBO Indústria Cirúrgica e Óptica S.A., Campinas, SP, Brazil) and a 25/5-caliber needle (Becton-Dickinson, São Paulo, SP, Brazil). After irrigation, excess solution was suctioned with a 40-20 cannula (Ibrás CBO Indústria Cirúrgica e Óptica S.A.). Gauze moistened in saline was used to clean the instrument shaft.

The preparation followed the crown-down pressureless technique. The simulate canal negotiation was realized with a size $10 \mathrm{~K}$ file. The working length determination (WL) was set at $16 \mathrm{~mm}$ by visual method. Light push and pull movements were applied to K3 instruments in a pecking motion and minimal crowndown pressure was applied for approximately $10 \mathrm{~s}$. For ProTaper Universal instruments, pecking motion and soft traction movements were made against the root canal walls with S1 and S2 instruments. Pecking motion was applied for F1, F2, F3, F4, F5 instruments for approximately $10 \mathrm{~s}$. All instruments of K3 system and all finishing instruments of ProTaper Universal system were used for apical stop preparation.

The data had a parametric distribution. Interaction

Table 1. Force means (N) and standard deviation for 40 degrees of curvature at a $1-\mathrm{mm}$ distance from the shaft tip for instruments from the K3 System after 0, 1, 3 and 5 uses.

\begin{tabular}{|c|c|c|c|c|c|}
\hline \multirow{2}{*}{ Instrument } & \multicolumn{4}{|c|}{ Number of uses } & \multirow{2}{*}{ Total } \\
\hline & 0 & 1 & 3 & 5 & \\
\hline 15 & $\begin{array}{c}1.64 \\
(0.79)\end{array}$ & $\begin{array}{c}1.24 \\
(0.44)\end{array}$ & $\begin{array}{c}2.80 \\
(1.02)\end{array}$ & $\begin{array}{c}2.94 \\
(0.93)\end{array}$ & $\begin{array}{l}2.16^{\mathrm{C}} \\
(1.07)\end{array}$ \\
\hline 20 & $\begin{array}{c}2.78 \\
(0.90)\end{array}$ & $\begin{array}{c}2.66 \\
(0.58)\end{array}$ & $\begin{array}{c}3.00 \\
(0.67)\end{array}$ & $\begin{array}{c}2.94 \\
(0.67)\end{array}$ & $\begin{array}{c}2.85^{\mathrm{BC}} \\
(0.67)\end{array}$ \\
\hline 25 & $\begin{array}{c}2.68 \\
(0.36)\end{array}$ & $\begin{array}{c}2.50 \\
(0.39)\end{array}$ & $\begin{array}{c}3.24 \\
(0.49)\end{array}$ & $\begin{array}{c}3.32 \\
(0.50)\end{array}$ & $\begin{array}{c}2.94^{\mathrm{BC}} \\
(0.54)\end{array}$ \\
\hline 30 & $\begin{array}{c}2.50 \\
(0.60)\end{array}$ & $\begin{array}{c}3.16 \\
(1.14)\end{array}$ & $\begin{array}{c}4.10 \\
(0.51)\end{array}$ & $\begin{array}{c}3.96 \\
(0.58)\end{array}$ & $\begin{array}{l}3.43^{\mathrm{B}} \\
(0.96)\end{array}$ \\
\hline 35 & $\begin{array}{c}3.12 \\
(1.06)\end{array}$ & $\begin{array}{c}3.46 \\
(0.55)\end{array}$ & $\begin{array}{c}4.06 \\
(0.76)\end{array}$ & $\begin{array}{c}4.18 \\
(0.73)\end{array}$ & $\begin{array}{l}3.71^{\mathrm{B}} \\
(0.86)\end{array}$ \\
\hline 40 & $\begin{array}{c}3.44 \\
(1.40)\end{array}$ & $\begin{array}{c}3.92 \\
(0.68)\end{array}$ & $\begin{array}{c}6.12 \\
(0.91)\end{array}$ & $\begin{array}{c}5.92 \\
(1.11)\end{array}$ & $\begin{array}{l}4.85^{\mathrm{A}} \\
(1.56)\end{array}$ \\
\hline 45 & $\begin{array}{c}3.98 \\
(2.47)\end{array}$ & $\begin{array}{c}4.80 \\
(0.72)\end{array}$ & $\begin{array}{c}6.08 \\
(1.14)\end{array}$ & $\begin{array}{c}6.16 \\
(0.61)\end{array}$ & $\begin{array}{c}5.26^{\mathrm{A}} \\
(1.62)\end{array}$ \\
\hline Total & $\begin{array}{c}2.88^{b} \\
(1.34)\end{array}$ & $\begin{array}{c}3.11^{\mathrm{b}} \\
(1.23)\end{array}$ & $\begin{array}{l}4.20^{\mathrm{a}} \\
(1.50)\end{array}$ & $\begin{array}{c}4.20^{\mathrm{a}} \\
(1.44)\end{array}$ & $\begin{array}{c}3.60 \\
(1.50)\end{array}$ \\
\hline
\end{tabular}

Means followed by different uppercase letters in columns and different lowercase letters in rows are significantly different $(\mathrm{p}<0.05)$. between the instrument and the number of uses was analyzed by ANOVA and Tukey's multiple-comparison test at 5\% level of significance.

\section{RESULTS}

The statistical analyses performed for both systems showed that there was no significant interaction between the instrument and the number of uses. Regardless of how many times it was used, instrument 15 of the K3 system (Sybron Endo) had the lowest mean curvature force, significantly lower than that of instruments 30 and $45(\mathrm{p}<0.05)$. Instruments 30 and 35 presented significantly lower force means than instruments 40 and $45(\mathrm{p}<0.05)$ (Table 1 and Fig. 1). Among instruments of the ProTaper Universal system (Dentsply Maillefer), S1 and S2 presented the lowest means of curvature force, regardless of how many times they were used $(p<0.05)$. Instruments $\mathrm{F} 4$ and $\mathrm{F} 5$ presented lower force means than those of instruments F2 and F3 ( $p<0.05$ ) (Table 2 and Fig. 1). Finally, regardless of the instrument analyzed, uses 0 and 1 presented significantly lower force means than

Table 2. Force means (N) and standard deviation for 40 degrees of curvature at a 1-mm distance from the shaft tip for instruments from the ProTaper Universal System after 0, 1, 3 and 5 uses.

\begin{tabular}{|c|c|c|c|c|c|}
\hline \multirow{2}{*}{ Instrument } & \multicolumn{4}{|c|}{ Number of uses } & \multirow{2}{*}{ Total } \\
\hline & 0 & 1 & 3 & 5 & \\
\hline $\mathrm{S} 1$ & $\begin{array}{c}1.96 \\
(0.93)\end{array}$ & $\begin{array}{c}2.34 \\
(0.61)\end{array}$ & $\begin{array}{c}3.18 \\
(1.04)\end{array}$ & $\begin{array}{c}3.70 \\
(0.60)\end{array}$ & $\begin{array}{l}2.80^{\mathrm{C}} \\
(1.03)\end{array}$ \\
\hline $\mathrm{S} 2$ & $\begin{array}{c}2.10 \\
(0.66)\end{array}$ & $\begin{array}{c}2.60 \\
(0.55)\end{array}$ & $\begin{array}{c}4.14 \\
(1.02)\end{array}$ & $\begin{array}{c}4.40 \\
(0.64)\end{array}$ & $\begin{array}{l}3.31^{\mathrm{C}} \\
(1.21)\end{array}$ \\
\hline $\mathrm{F} 1$ & $\begin{array}{c}5.34 \\
(0.86)\end{array}$ & $\begin{array}{c}4.76 \\
(1.01)\end{array}$ & $\begin{array}{c}6.26 \\
(0.40)\end{array}$ & $\begin{array}{c}6.38 \\
(0.53)\end{array}$ & $\begin{array}{l}5.69^{\mathrm{B}} \\
(0.97)\end{array}$ \\
\hline $\mathrm{F} 2$ & $\begin{array}{c}6.54 \\
(0.92)\end{array}$ & $\begin{array}{c}6.48 \\
(1.15)\end{array}$ & $\begin{array}{c}9.66 \\
(2.67)\end{array}$ & $\begin{array}{c}8.98 \\
(1.49)\end{array}$ & $\begin{array}{l}7.92^{\mathrm{A}} \\
(2.14)\end{array}$ \\
\hline F3 & $\begin{array}{c}8.06 \\
(1.25)\end{array}$ & $\begin{array}{c}6.98 \\
(0.31)\end{array}$ & $\begin{array}{c}8.42 \\
(1.31)\end{array}$ & $\begin{array}{c}9.74 \\
(1.00)\end{array}$ & $\begin{array}{l}8.30^{\mathrm{A}} \\
(1.40)\end{array}$ \\
\hline F4 & $\begin{array}{c}6.08 \\
(0.71)\end{array}$ & $\begin{array}{c}6.90 \\
(0.96)\end{array}$ & $\begin{array}{c}6.80 \\
(1.31)\end{array}$ & $\begin{array}{c}6.54 \\
(1.34)\end{array}$ & $\begin{array}{l}6.58^{\mathrm{B}} \\
(1.07)\end{array}$ \\
\hline F5 & $\begin{array}{c}5.44 \\
(0.92)\end{array}$ & $\begin{array}{c}6.30 \\
(1.10)\end{array}$ & $\begin{array}{c}6.92 \\
(1.75)\end{array}$ & $\begin{array}{c}7.56 \\
(1.71)\end{array}$ & $\begin{array}{l}6.56^{\mathrm{B}} \\
(1.53)\end{array}$ \\
\hline Total & $\begin{array}{l}5.07^{b} \\
(2.28)\end{array}$ & $\begin{array}{l}5.19^{b} \\
(2.04)\end{array}$ & $\begin{array}{l}6.48^{\mathrm{a}} \\
(2.52)\end{array}$ & $\begin{array}{l}6.76^{\mathrm{a}} \\
(2.33)\end{array}$ & $\begin{array}{c}5.88 \\
(2.40)\end{array}$ \\
\hline
\end{tabular}

Means followed by different uppercase letters in columns and different lowercase letters in rows are significantly different $(\mathrm{p}<0.05)$. 
uses 3 and $5(\mathrm{p}<0.05)$ for both systems (Tables 1 and 2$)$.

\section{DISCUSSION}

Important factors for validating the data collected were using simulated canals $(5,12)$, conducting a pilot project and training the operator. On the other hand, it is known that cleansing and sterilization procedures, used here to approximate the study to clinical conditions, may influence the results. Thus, further studies using a control group without cleansing and sterilization should be considered.

The mechanical test used in the present study was similar to that described by Camps and Pertot (16), who also used an instrument fixed on one end (cantilever), while applying the force on the opposite end. The rigid nature of the copper wire used in the study prevented any wire deformations from being confounded with those of the instrument. The changes we made in relation to the suggestions of the American National Standards Institute, American Dental Association Specification no. 28 (17), namely our option for a 40-degree curvature and for fastening the instrument at $1 \mathrm{~mm}$ from the tip, had the purpose of rendering the measurements more accurate.

Although not an objective of the study, it was observed that each type of instrument displayed a

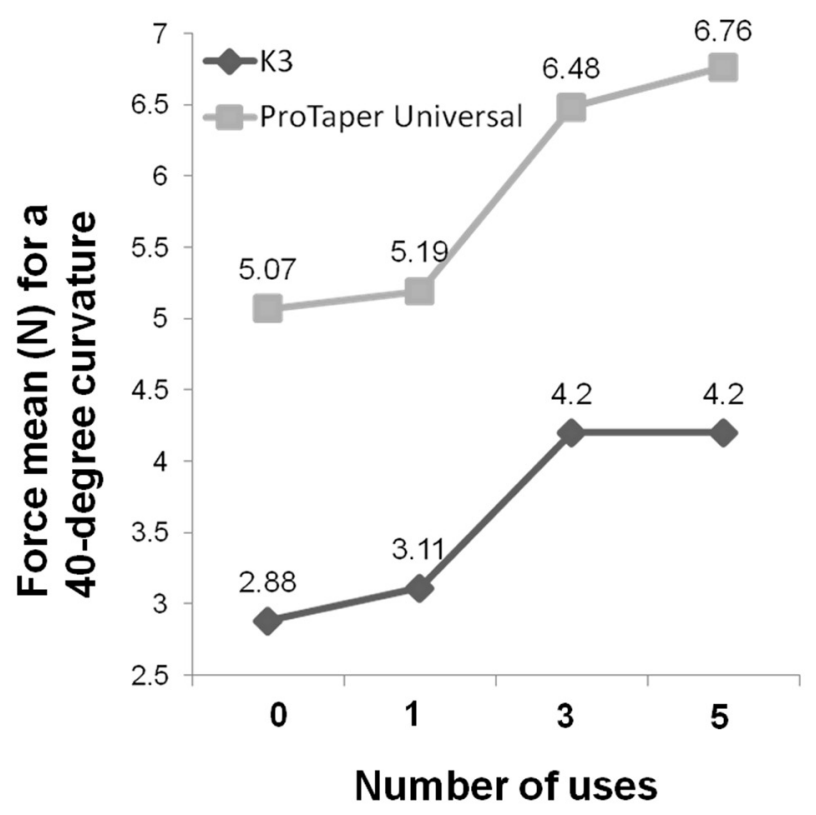

Figure 1. Force means $(\mathrm{N})$ required for producing a 40-degree curvature according to the number of uses, for the K 3 and ProTaper Universal systems. different curvature radius, when analyzing its form in the photographs. Thus, as already demonstrated in the related literature, the magnitude of flexion is load-dependent, but the curve form is not $(8,11)$.

The most important result of the present study which rejects the null hypothesis - is that, regardless of the instrument studied and in both systems, significantly greater force means required to produce the curvature were observed after the third and fifth uses, compared to those required in uses 0 and 1 . This means that the instruments became less flexible after the third use and maintained the same flexibility after the fifth use.

Kuhn and Jordan (1) demonstrated that the rigidity of instruments used in canals with abrupt curvatures increased after each use. Hence, an instrument that has already been used may exert greater force on the wall of a curved canal as a result of greater rigidity and increased resetting force. These changes in the instrument will produce undesirable anatomic characteristics in the canal $(6,12)$.

The most flexible instrument of the K3 system (Sybron Endo) was the one with the smallest diameter, irrespective of the number of uses, since all of the instruments had the same conicity, as already demonstrated in the related literature (19). Instruments S1 and S2 of the ProTaper Universal system (Dentsply Maillefer) presented significantly greater flexibility compared to the finishing instruments. This can be explained by the fact that the shaping instruments have greater flexibility at the tip because of their increasing conicity along the shaft (19). Câmara et al. (20) reported that one of the main changes occurring in the ProTaper Universal in relation to the ProTaper was a flexibility increase in instruments F1 and S1. However, the authors observed a decrease in this property in instruments F2 and F3. This fact may help explain the findings of the present study, where instruments $\mathrm{F} 2$ and $\mathrm{F} 3$ presented the lowest flexibility values among all ProTaper Universal instruments. Improved properties are achieved by streamlining geometric characteristics (7), and this may explain the similar flexibility of instruments F4, $\mathrm{F} 5$ and $\mathrm{F} 1$.

Within the limitations of this study, it may be concluded that: 1 . As regards the number of uses, instruments of both systems presented lower flexibility after the third use, as compared to those of uses 0 and 1 , and maintained the same flexibility after the fifth use; 2. Flexibility of K3 system instruments decreased with the increase of diameter, irrespective of the number 
of uses. 3. The shaping instruments of the ProTaper Universal system presented greater flexibility than the finishing instruments. 4. F2 and F3 were the least flexible instruments, while $\mathrm{F} 4$ and $\mathrm{F} 5$ presented flexibility values similar to those of F1.

\section{RESUMO}

Esta pesquisa estudou a flexibilidade de instrumentos do Sistema K3 (conicidade 0.04) e do Sistema ProTaper Universal, por meio de um teste mecânico, quando os instrumentos eram novos e após 5 usos em canais simulados. Cinco jogos de instrumentos de cada sistema foram testados, como segue: grupo I - K3 (15, 20, 25, 30, 35, 40 e 45), e grupo II - ProTaper Universal (S1, S2, F1, F2, F3, F4 e F5). Cada jogo de instrumento foi usado para preparar um canal simulado, e o mesmo jogo de instrumento foi usado 5 vezes (50 canais). $\mathrm{O}$ número de cada subgrupo representou o número de usos: 0 (controle), 1, 3 e 5 usos. Antes do uso e depois de cada uso os instrumentos foram submetidos a um teste mecânico de flexibilidade realizado na máquina de ensaios universais Versat 502. A interação entre o instrumento e o número de usos foi analisada pelo ANOVA e pelo teste de Tukey ao nível de significância 5\%. Instrumentos de ambos os sistemas apresentaram menor flexibilidade após o terceiro uso quando comparada com a flexibilidade após os usos 0 e 1 $(\mathrm{p}<0,05)$, e mantiveram a mesma flexibilidade após o quinto uso. A flexibilidade dos instrumentos do sistema K3 diminuiu conforme o aumento de diâmetro, independente do número de usos. Entre os instrumentos do sistema ProTaper Universal, os shaping apresentaram maior flexibilidade que os finishing. F2 e F3 foram os menos flexíveis e F4 e F5 apresentaram valores de flexibilidade similares ao F1.

\section{ACKNOWLEDGEMENTS}

This paper is dedicated to the memory of Professor Orlando Limongi, a great mentor and pioneer of the implementation of the crown-down technique and rotary instrumentation research conducted at the Lutheran University of Brazil (ULBRA).

\section{REFERENCES}

1. Kuhn G, Jordan L. Fatigue and mechanical properties of nickeltitanium endodontic instruments. J Endod 2002;28:716-720.

2. Miyai K, Ebihara A, Hayashi Y, Doi H, Suda H, Yoneyama T. Influence of phase transformation on the torsional and bending properties of nickel-titanium rotary endodontic instruments. Int Endod J 2006;39:119-126.

3. Zinelis S, Eliades T, Eliades G. A metallurgical characterization of ten endodontic Ni-Ti instruments: assessing the clinical relevance of shape memory and superelastic properties of Ni-Ti endodontic instruments. Int Endod J 2010;43:125-134.

4. Turpin YL, Chagneau F, Vulcain JM. Impact of two theoretical cross-sections on torsional and bending stresses of nickel-titanium root canal instrument models. J Endod 2000;26:414-417.

5. Schäfer E, Vlassis M. Comparative investigation of two rotary nickel-titanium instruments: ProTaper versus RaCe. Part 1. Shaping ability in simulated curved canals. Int Endod J 2004;37:229-238.

6. Simon S. Endodontic shaping with an adapted Pitch. Dent Update 2010;37:97-100, 102-103.

7. He R, Ni J. Design improvement and failure reduction of endodontic files through finite element analysis: application to V-Taper file designs. J Endod 2010;36:1552-1557.

8. Gambarini G. Cyclic fatigue of nickel-titanium rotary instruments after clinical use with low-and high-torque endodontic motors. J Endod 2001;27:772-774.

9. Cheung GS, Darvell BW. Low-cycle fatigue of NiTi rotary instruments of various cross-sectional shapes. Int Endod J 2007;40:626-632.

10. Chevalier V, Arbab-Chirani R, Arbab-Chirani S, Calloch S. An improved model of 3-dimensional finite element analysis of mechanical behavior of endodontic instruments. Oral Surg Oral Med Oral Pathol Oral Radiol Endod 2010;109:111-121.

11. Necchi S, Petrini L, Taschieri S, Migliavacca F. A comparative computational analysis of the mechanical behavior of two nickeltitanium rotary endodontic instruments. J Endod 2010;36:13801384.

12. Troian CH, Só MV, Figueiredo JA, Oliveira EP. Deformation and fracture of RaCe and $\mathrm{K} 3$ endodontic instruments according to the number of uses. Int Endod J 2006;39:616-625.

13. Wolcott S, Wolcott J, Ishley D, Kennedy W, Johnson S, Minnich S, et al.. Separation incidence of Protaper rotary instruments: a large cohort clinical evaluation. J Endod 2006;32:1139-1141.

14. You SY, Bae KS, Baek SH, Kum KY, Shon WJ, Lee W. Lifespan of one nickel-titanium rotary file with reciprocating motion in curved root canals. J Endod 2010;36:1991-1994.

15. Varela-Patiño $P$, Ibañez-Párraga A, Rivas-Mundiña B, Cantatore $\mathrm{G}$, Otero XL, Martin-Biedma B. Alternating versus continuous rotation: a comparative study of the effect on instrument life. J Endod 2010;36:157-159.

16. Camps J, Pertot WJ. Torsional and stiffness properties of Canal Master U stainless steel and nitinol instruments. J Endod 1994;20:395-398.

17. ANSI/ADA Council on Dental Materials and Devices. New American Dental Association Specification no. 28 for endodontic files and reamers. Council on Dental Materials and Devices. J Am Dent Assoc 1976;93:813-817.

18. Low D, Ho AW, Cheung GS, Darvell BW. Mathematical modeling of flexural behavior of rotary nickel-titanium endodontic instruments. J Endod 2006;32:545-548.

19. Bergmans L, Van Cleynenbreugel J, Beullens M, Wevers M, Van Meerbeek B, Lambrechts P. Progressive versus constant tapered shaft design using NiTi rotary instruments. Int Endod J 2003;36:288-295.

20. Câmara AS, de Castro Martins R, Viana AC, de Toledo Leonardo R, Buono VT, de Azevedo Bahia MG. Flexibility and torsional strength of ProTaper and ProTaper Universal rotary instruments assessed by mechanical tests. J Endod 2009;35:113-116.

Accepted April 4, 2011 